\title{
脊損神経因性膀胼に対する根治的経尿道的前立腺切除術
}

\author{
第 1 報 その臨床的有用性について \\ 北海道大学医学部泌尿器科教室（主任：小柳知彦教授) \\ 森田肇窪田 理裕 小柳 知彦 \\ 美唄労災病院泌尿器科 \\ 高松恒夫

\section{RADICAL TRANSURETHRAL RESECTION OF PROSTATE FOR SPINAL CORD INJURY PATIENTS} \\ I. Its Clinical Therapeutic Effects \\ Hajime Morita, Michihiro Kubota and Tomohiko Koyanagi \\ Department of Urology, Hokkaido University School of Medicine \\ (Director: Prof. Tomohiko Koyanagi) \\ Tsuneo Takamatsu \\ Department of Urology, Bibai Rousai Hospital
}

The clinical therapeutic efficacy of radical transurethral resection of the prostate was studied in 100 spinal cord injury patients who had voiding disorder and were not responsive to conservative therapy.

90 of the 100 patients became free of catheter after radical TUR-P by attaining satisfactory voiding parameters. Postoperative deterioration of incontinence was not seen and incontinence was rather improved in most of the cases.

The vesicoureteral reflux was abolished in 16 of 28 ureters and ameliorated in 3 ureters. Hydronephroureters were normalized or improved in 10 of 11 patients.

In 13 cases voiding disturbance recurred but 10 patients were rendered catheter-free again after appropriate treatments.

5 patients of mostly high level cervical cord injury were with frank failures.

This study confirmed that radical TUR-P is clinically effective for the spinal cord injury patients except high level tetraplegics.

\begin{abstract}
要旨：昭和52年 1 月以降, 美唄労災病院泌尿器科で radical TUR-P を施行した100例の慢性期脊損症例 について, 本法の臨床的有用性を検討した. 100例中 80 例は，本術式施行後自排尿可能となった。その術 前後の残尿率は，それぞれ， $46.9 \pm 34.4 \% ， 8.1 \pm 9.9 \%$ と術後に有意の低下をみた。尿流量率も，術前 $54 \pm 72 \mathrm{ml} / \mathrm{min}$, 術後 $207 \pm 166 \mathrm{ml} / \mathrm{min}$ と術後に有意の増加がみられた。尿失禁は, 術後一時増悪するも のはあるが，長期成績では尿失禁の増強をみた例は，ほとんどなかった。レ線上，術前に存在した VUR 20例28尿管のうち19尿管において，その軽减ないし消失がみられ，水腎水尿管を呈した11例も，術後10 例で軽減, 正常化を認めた。膀胱変形のみられた症例でもその大多数に術後の改善をみている. 初回術 後しばらくして排尿障害の再発をみた13例は，その原因を検索し，それぞれの原因に応じた治療によっ て10例が再度自排尿可能となり, 結局全体で90例（90\%）をカテーテルフリーとすることができた，高 位䅡損の 5 例は, 術後も自排尿不能で, 膀朕瘦による尿路管理とした。術後の長期成績から, 高位䅡損 を除く脊損神経因性膀胼に対し，本法は臨床的に有用と考兄られた。
\end{abstract}

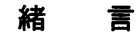

脊髄損傷において排尿障害は多少の差はあれほぼ必 発であり, 従来より種々の治療法が試みられ, ことに
近年各種薬物療法の進歩 ${ }^{11}$ や間欠的自己導尿法 ${ }^{2}$ の普 及にともない，脊損者の排尿管理は格段の進歩をみた といっても過言でない.しかし，このような保存的治 
療のみではカテーテルフリーの状態で十分な排尿効率 の改善を得られない症例が少なくないことも事実で, これらに対しては外科的治療として主に外尿道括約筋 切開術が行なわれてきた。この方法は残尿を減少させ， カテーテルフリーの状態にすることがでさるという点 で確かに有効な術式と言学るが，反面術後に生じる高 度の尿失禁に対する処置が必要であり，患者はこれに 伴ら種々の問題に悩むされることが少なくない。この ような見地から1981年 Koyanagi ら ${ }^{3)}$ は尿失禁を増悪 させることなく，かつ排尿障害の改善をめざした方法 として根治的経尿道的前立腺切除術を報告した。

本法の治療成績については，すでにいくつかの報告 があるが3(4)，本術式施行例の増加にともない，その有 用性について臨床的見地から，その長期成績を追試検 討し，あわせて術後排尿障害再発例についても検討を 加えたので以下に報告する。

\section{対象及び方法}

昭和 52 年 1 月以降, 美唄労災病院泌尿器科にて尿路 管理を行なっていた慢性期脊損症例のうち，排尿障害 の治療として radical transurethral resection of prostate (以下 radical TUR-P) を施行した100例を対象と した。年齿令は21歳から 72 歳, 平均 49 歳, 受傷部位は, 椎骨レベルで，顗椎22例（不全損傷 4 例，中心性損傷 7 例), 胸椎 40 例, 腰椎 38 例(不全損傷 1 例)であった。 受傷より本法施行までの期間は 6 力月から 21 年 8 力 月, 平均 8 年 4 カ月であった. 本法を施行するにあたっ ての適応として,1）各種保存療法にても排尿障害の改 善がみられず, 自排尿不能のため, 膀胼瘦や尿道留置 カテーテルのもの, あるいはセルフカテーテルのもの, また自排尿ではあっても良好で安定した排尿効率（残 尿率 $20 \%$ 以下，尿流量率 $100 \mathrm{ml} / \mathrm{min}$ 以上，排尿圧 $70 \mathrm{~cm}$ 水柱以下）が得られず，自覚的にも排尿困難を訴える
症例, 2）必ずしも排尿障害の自覚がないにもかかわら ずレ線検查にて，水腎水尿管や，腎機能低下，膀胼変

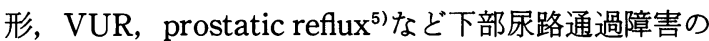
存在が疑われるもの无を対象とした。

これらの症例に対し，既報3に準じた方法で radical TUR-Pを施行し，術前後の排尿状態を評価するため に術前 $1 \sim 2$ 週, 術後 3 週 3 力月の時点で残尿率測 定, 尿流量率測定, IVP, 排尿時造影等のレ線検査を施 行した.

これらの検査所見から，術後他覚的に排尿効率の改 善がみられたものは，カテーテルフリーとして以後 6 カ月ないし 1 年毎に経過観察を行ない，自覚的に排尿 困難や発熱など症状をともなら尿路感染がなく，他覚 的にもレ線上の異常所見や尿所見の異常を認めないも のを長期成績安定例とした。一方, 術後の経過観察中, 排尿障害の再発のみられた症例に対しては下部尿路機 能検査を含め再発の原因を検索し，それに応じた治療 法を施行した。

\section{結果}

\section{1. 臨床成績（図 1 )}

術後カテーテルフリーで自排尿可能となり，以後自 他覚的に良好で安定した排尿状態を保ち，レ線所見か らも尿路の状態に異常を認めない症例は，80例であっ た。その経過観察の期間は 1 力月から 9 年 3 力月, 平 均 4 年11カ月である.これらのらち, 術前後に残尿率, 尿流量率を測定した症例につき, その変化を検討した。 残尿率は術前 $46.9 \pm 34.4 \%(\mathrm{Mean} \pm$ S.D.), 術後 $8.1 \pm$ 9.9\%（Mean \pm S.D.）で， $\mathrm{t}$ 検定にて術後有意の低下 $(\mathrm{p}<0.05)$ がみられ（図 2)，尿流量率も術前 $54 \pm 72 \mathrm{ml} /$ $\min ($ Mean \pm S.D.), 術後 $207 \pm 166 \mathrm{ml} / \mathrm{min}$ (Mean \pm S. D.）と術後に有意の増加（p<0.05）が認められた（図 3 ).

図 1 術後の排尿法

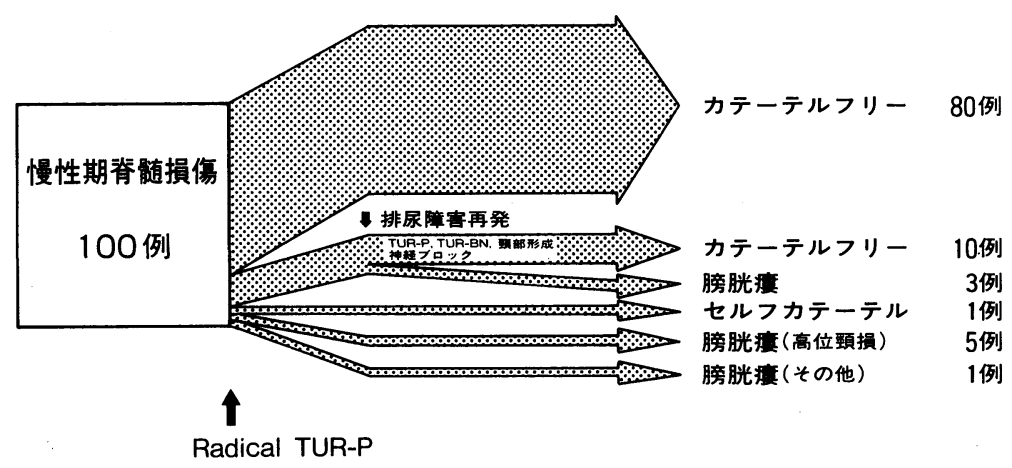


図 2 術前後の残尿率

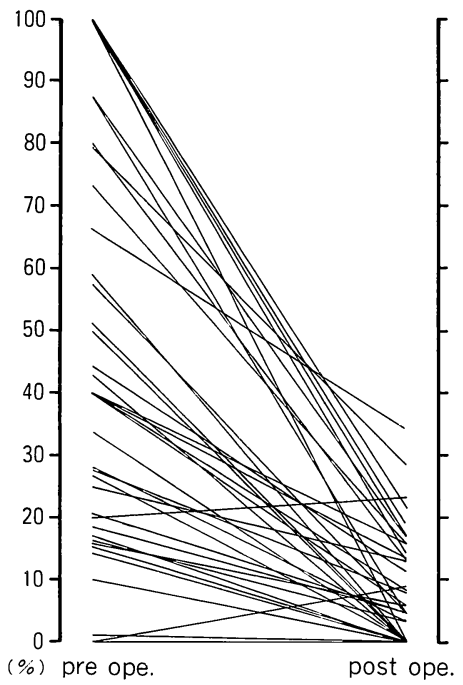

図 3 術前後の尿流量率

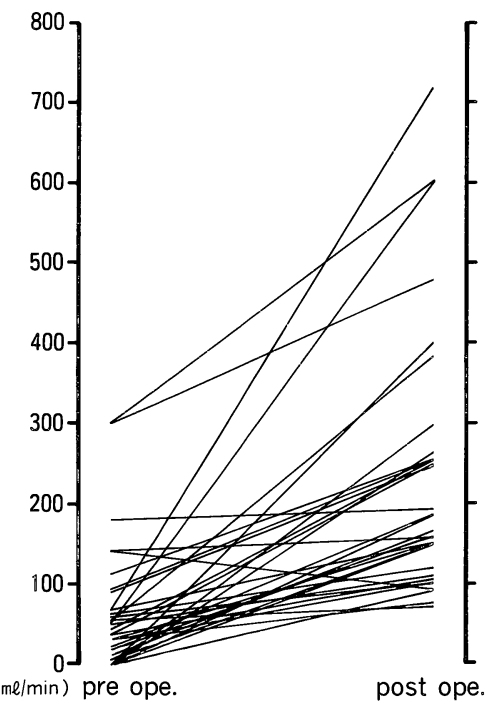

な报術前から多少の差はあれ，尿失禁を認めた例が 少なくないが，本法施行後，一時的に尿失禁の増悪を みることがあるものの，長期的には軽減ないし消失す るものが多く, 術前にみられた尿失禁が術後に増強し たものは臣とんどなかった。

術後自排尿可能となったが，その後の経過観察中に 排尿障害の再発がみられたものが13例あった。術後再 発玉での期間は 1 力月から 4 年 5 力月, 平均 1 年 3 力 月であった。これらに対し再発の原因検索のため, 内 視鏡検査, レ線検査, 水力学的検査等を施行したが,
これらの結果から,1）前立腺尖部組織の残存によるも の ( 6 例)，2）外尿道括約筋筋電図上, 術前に存在し た利尿笳括約筋協調不全 (以下 DSD) の再発, 悪化に よるもの（2 例)，3）1)及び2)の両者の関与によると 思われるもの ( 2 例), 4) 術後膀脱頝部硬化症による もの（3 例）がその原因として考えられた。これらに 対し，それぞれの原因に応じた治療法を施行した。す なわち1)及び2)の場合には，残存尖部組織に対し再度 のTUR-Pを行ない，2)に対しては，クモ膜下神経ブ ロックを，4）に対しては TUR-bladder neck などを施 行した。再発例13例中10例は，これらの治療により再 度カテーテルフリーとすることができ，これらの再手 術成功例を含めると結局90例（90\%）が長期成績安定 の成功例といえる。なお 3 例は本人の希望から膀胼瘻 による尿路管理を選択した。術後も自排尿不能でカ テーテルフリーとすることができなかった症例は, 100 例中 7 例あり， らち 5 例は高位頝損例でこれらは術前 から存在した DSD が術後も改善せず，また排尿に必 要な腹圧や上肢の十分な筋力が得られないものが多い ことから, 自排尿不能と判断し, やむなく膀胱㾞とし た。なた精神病から術後陰茎自己切断により自排尿不 能となった 1 例も膀胱瘦となった。な抏, 術中出血の ため前立腺組織遺残のます手術を中止した 1 例は，再 度の手術を希望せず以後セルフカテーテルによる尿路 管理とした。

2.レ線検查所見

a）水腎水尿管の変化

術前に下部尿路通過障害に伴ら上部尿路拡張のらち VURを伴わない症例が11例みられた. radical TUR-P 後, らち10例に水腎水尿管の軽減ないし消失がみられ (図 4)，1 例は不変であった。

b) VURの変化（図 5 )

術前にVUR の存在した症例は20例あり, 片側性の もの12例，両側性のもの 8 例，計28尿管であった。術

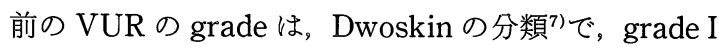
7 例, grade IIa 8 例, grade IIb 6 例, grade III 6 例, grade IV 1 例であった. radical TUR-P 後,このらち 16尿管に VURの消失がみられた，3尿管で grade の 低下, 8 尿管で不変, 1 尿管で gradeの上昇を認めた。 grade Iの症例で, 例外的に術後の増悪をみたものがあ るが, grade III 以下の症例では概して VUR の消失軽 減をみるものが多い傾向にあった。

c）膀胱変形の変化

レ線上。膀胱に壁の不整や肉柱形成, 䄭室様変化な 
図 4 術前後の IVP. 術後両側水腎症の著明な改善がみられた.

術前

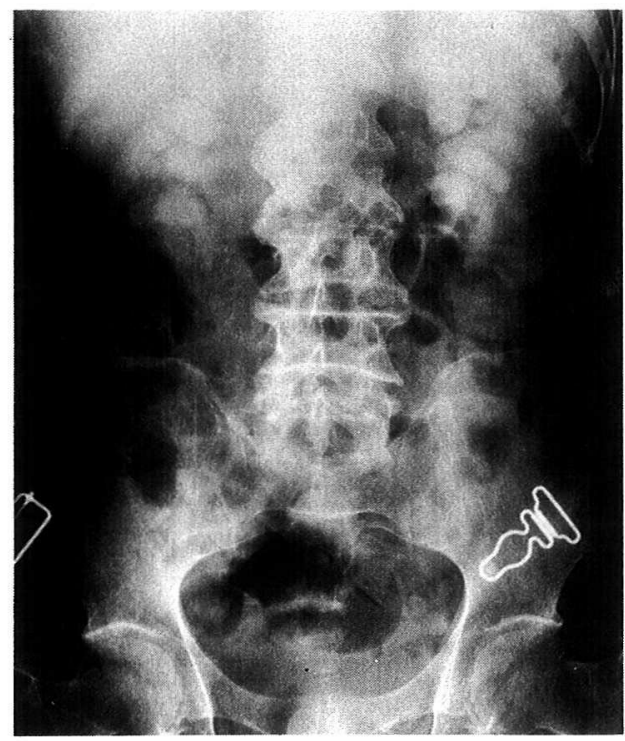

図 5 術前後の VUR の変化

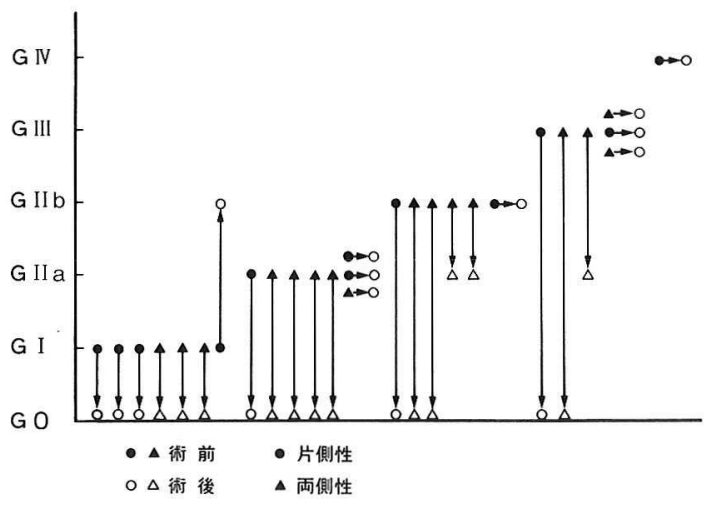

どの変形が62例に認められたが，本法を施行した後こ れらの膀胱変形に増強を認めたものはなく，12例で不 変，50例で軽減ないし消失が認められた（図 6 ).

\section{考案}

春損者に打ける尿路管理の重要性は, 従来より生命 予後をも左右するものとして強調されてきた。脊損者 の多くは受傷後, 急性期を経て種々の保存療法により, 自排尿可能となっていくが，このような治療によって も排尿障害の改善がみられないものや，経過中に下部 尿路通過障害に起因寸る膀胱変形や，上部尿路拡張， VURをみる例も少なくなくこのような症例に対し ては，外科的治療法として外尿道括約筋切開術をはじ
術後

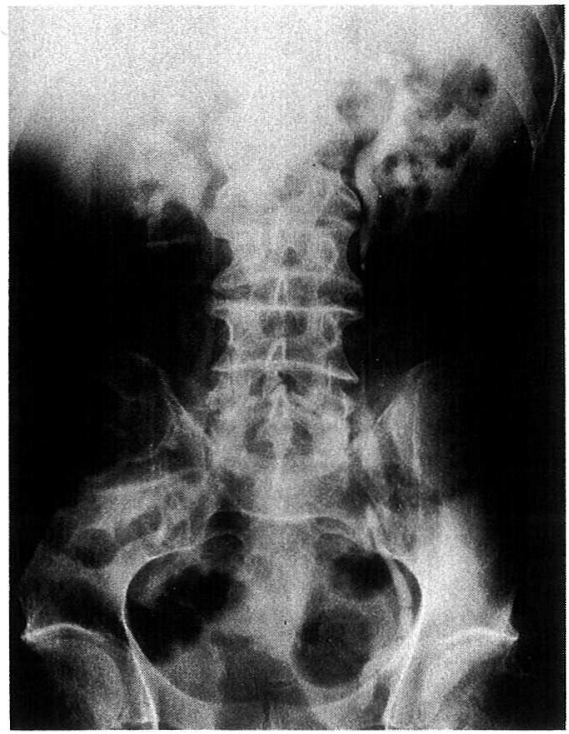

めとする各種の TUR 法が行なわれてきた。この術式 は下部尿路通過障害を解除し, low pressure system と することにより上部尿路に対する減圧効果を期待でき るといら点で, 確かに有効な方法であるが, 治療効果 が持続せず再手術を要する例がすくなくないこと辛, また排尿困難を軽減する一方で, 尿失禁の増強といら 別の排尿障害を若起することになる9 という点で，必 ずしも最善の方法とは言光ないと思われる。

1977年 Koyanagi らが報告した radical TUR-Pは, このような従来の TUR 法とは異なり，外尿道括約筋 を温存する術式である。すなわち本法は, 膀脱䅡部以 下の前立腺内腺部を通常の TUR-P に準じた方法で切 除し，さらに前立腺尖部に拈いて，McNeilのいう peripheral zone ${ }^{10)}$ の前立腺外腺部分をも, 解剖学的被 膜のレベルをで広沉に切除するものである。これは単 に下部尿路の器質的通過障害を除去するだけでなく， 脊損神経因性膀胱に扔いて hyperactive な状態にある と考兄られる壁内交感枝と，そのレセプターを前立腺 組織と共に切除することにより, “surgical sympathectomy”3) そも近い効果を狙った方法である。この 際, 外尿道括約筋は, intact に保たれることから, 術後 尿失禁の増強は殆どみられないわけである。

本法の治療効果については，小柳らがすでに報告し ているが，今回症例を増やし，その臨床成績について 追試及び再検討を加壳た。 
図 6 術前後の排尿時造影。術後の排尿時造影にて術前にみられた右 VUR と膀胼変 形の軽減が認められた。

術前

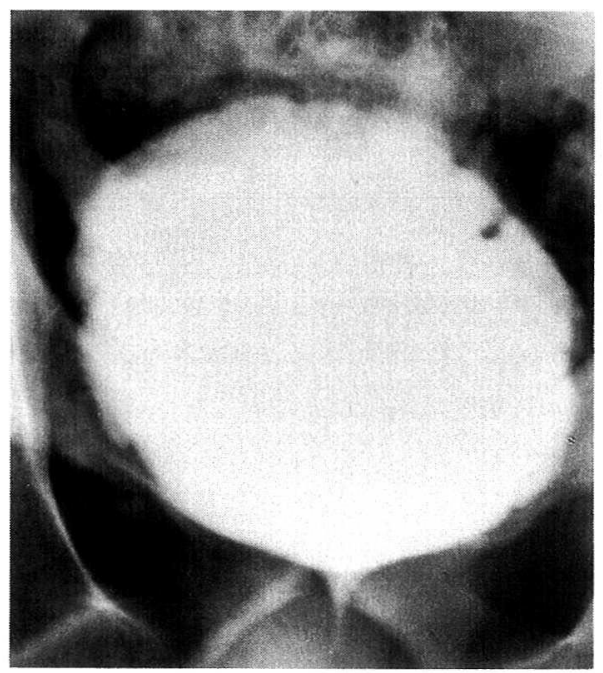

1）臨床成績

a）自排尿可能例

本法施行 100 例中 80 例は， 1 回の手術のみで, 排尿効 率の改善条件 (残尿率 $20 \%$ 以下, 平均尿流量率 $100 \mathrm{ml}$ / $\min$ 以上，排尿圧 $70 \mathrm{~cm}$ 水柱以下)を注ぼ満たすことが でき，自排尿可能となった。さらにこ机らは, 術後 6 カ月ないし 1 年毎の定期的経過観察にても安定した排 尿効率を保ち, 長期的にみた治療成績もすぐれていた。

このような長期成績安定例では，レ線上の特徵とし て切除後の前立腺窩は，フラスコ状に広く開大してお り，これは前立腺が尖部組織を含めて必要最大限に切 除されたことを示すものであり，この所見は術後の定 期レ線検査にても, 殆ど変化がみられなかった。一方, 尿の continence は前立腺窩の遠位部の外尿道括約筋 部で保たれており，排尿中にはこの部の弛緩が十分に 得られていた。

b）排尿障害再発例

術後，排尿障害が再発したものは13例あったが，そ の原因として，既に述べたように前立腺尖部組織の残 存や, それに伴う DSD の再発, 術後膀胱頚部硬化症の 発生などの関与が考兄られた。前立腺尖部組織の残存 は手術手技の巧拙によるもので，技法の習熟によりあ る程度防止可能であるが，術直後のレ線所見上，一見 前立腺窩の開大が十分に見光て子経過観察中に，排尿 障害の再発とともに尖部組織の残存が明らかになるこ とがあり注意を要する(図 7 )。このような変化は尖部
術後

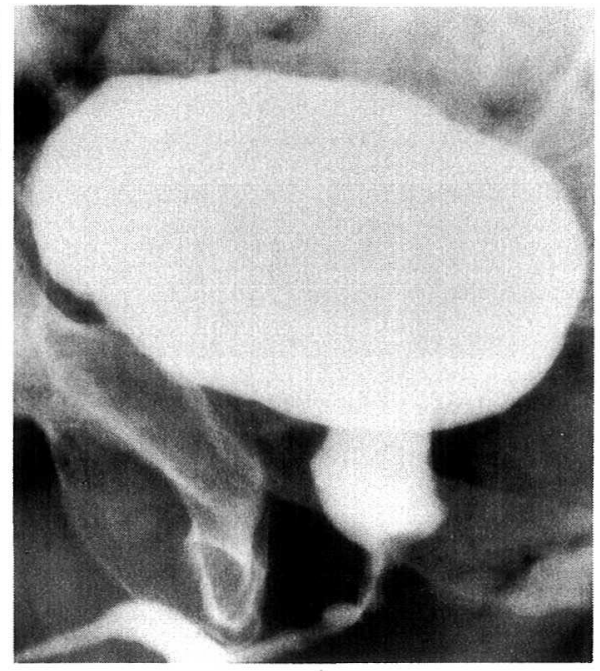

図 7 前立腺尖部組織残存例
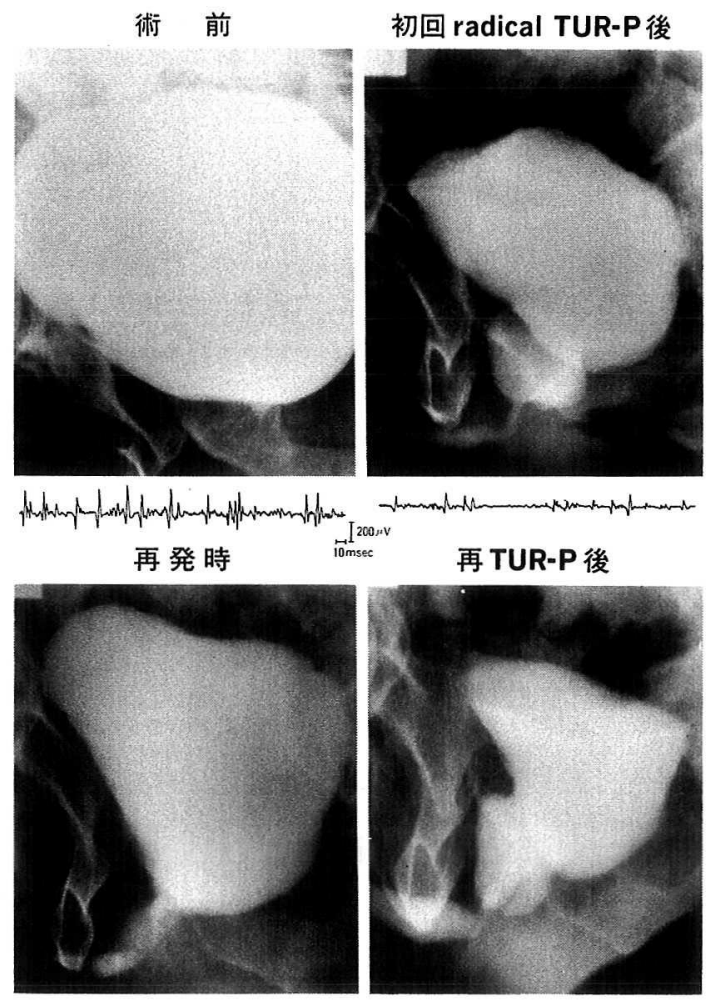

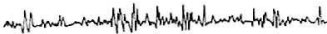

組織を湾ぼ完全に切除しえた症例ではみられない所見 である。この症例では外尿道括約筋筋電図上 DSD の 
図 8 術後膀胼䅡部硬化症例

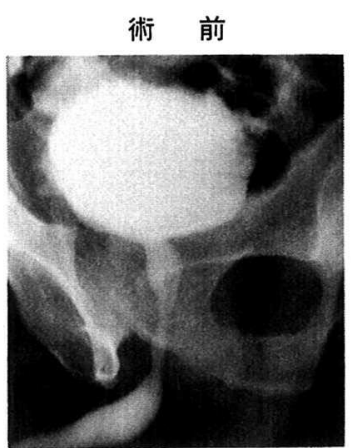

初回 radical TUR-P後

再 発時
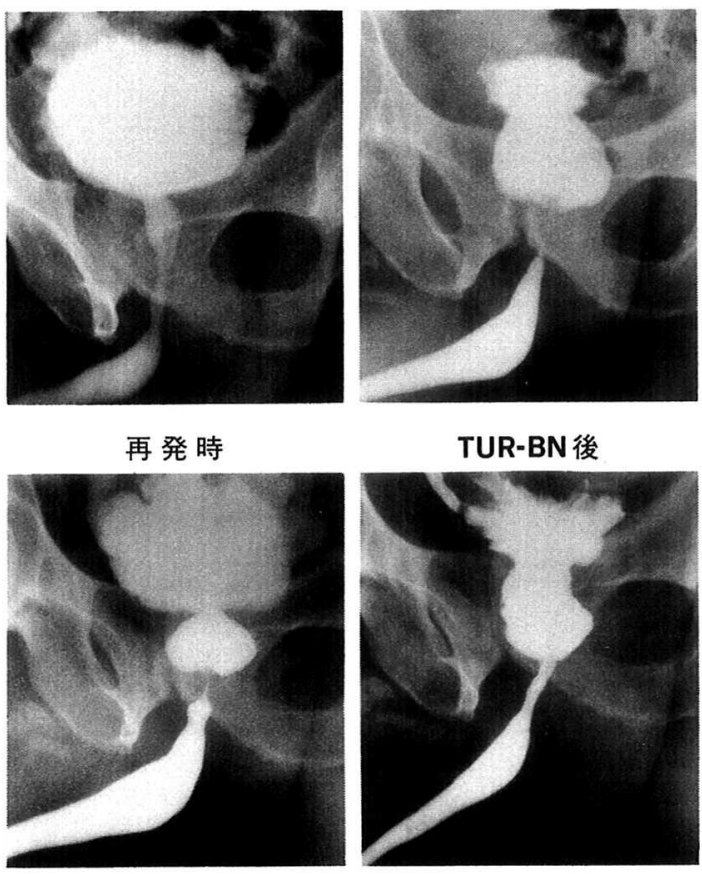

TUR-BN 後

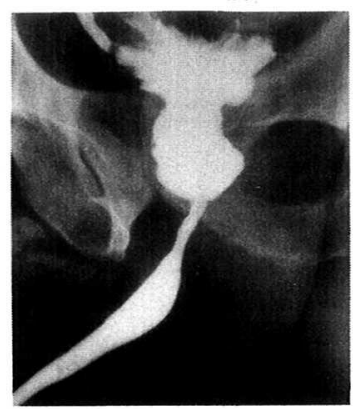

再発もみられていたが, 再度の TUR-Pにより DSD も 軽減し，臨床的にも排尿障害の改善がみられた。

内視鏡, レ線所見等から尖部組織の残存を認めない にもかかわらず, 高度の DSD のみられた例では, クモ 膜下神経ブロックにより外尿道括約笳の activity 消失させることで，排尿効率を改善させることができ た。

本術式の適応となる症例では必ずしも前立腺肥大症 の合併があるわけでなく, 実際の切除重量も10グラム 以下のことが多い。内視鏡上も膀胱頝部から後部尿道 にかけてはむしろ弛緩性に拡張し, 器質的通過障害の 所見をみない例が多い。このため不用意に膀胱頝部を 切除すると, 容易に頝部組織を損傷し, 術後膀胱䅡部 硬化症の原因となりらるため ${ }^{11}$ (図 8 ) 手術の際の注意 深い切除が望ま机る.

いずれにせよ本法施行後の排尿障害再発率は, Ruutu ら ${ }^{8)}$ の報告した脊損神経因性膀脱に対する外尿 道括約筋切開術後の再発率に比べ明らかに低く, 本法 の効果の長期持続性がうかがわれた。

c）自排尿不能例（特に高位䅡損について）

本法施行後も自排尿不能であった 7 例のらち 5 例は 高位䅡損の tetraplegia 例で, 術後種々の薬物療法を
試みたが効果なく，結局膀脱瘦となった。これらの症 例では排尿に必要な腹圧が不十分であり，また上肢筋 力が脆弱なため十分な手圧をかけることができないこ と, また詳細な機序は不明であるが, urodynamics 検 查上術後もDSD が残存する例が多く, 高位額損症例 に対しては本法は適応ではないとの印象を得た。この ような症例に対しては, 外尿道括約筋切開術あるいは 膀脱瘦が適応と考兄られるが，当科では膀胼瘦による 尿路管理を選択している。

d）尿失禁

radical TUR-Pでは外尿道括約筋を切除しないた め尿失禁の増悪をみないことが多い122。逆に術前から みられた尿失禁が術後むしろ軽減した例もみられ，こ の説明として，詳細は 2 報に述べるが, 膀胱の compliance の増加, detrusor hyperrflexia の軽減ないし消失 などが考兄られた。このように尿失禁の増悪をみない ことは, 各種 TUR 法の中で本法の特長の一つであり, 失禁対策に苦慮する必要がないといら点で優れた術式 と言兄よう。

2) レ線所見

a) VUR

脊損神経因性膀胼に発生する VUR の機序として, 下部尿路通過障害に起因寸る残尿の存在, 排尿動作時 に怙ける高い排尿圧による尿管膀脱移行部の逆流防止 筋構築の破壊, あるいは逆流防止に関与する神経機構 に対する影響などが考克られるが13114)，いずれにせよ VUR が脊損者に打いて腎機能低下を惹起する大きな 原因の一つであることは明らかである。高松によれ ば15), VUR の grade と DSD の程度の間に有意の相関 関係がみられ，また治療によるDSDの軽減消失が VURの軽快に深く関与していることが証明されてい る. 本法施行例に损いても100例中術前に VURを認め た20例28尿管のうち，19尿管に VUR の grade の改善 ないし消失を認めて抒り, 術後の DSD の軽減がこの 機序に関与しているものと思われた。このような点か ら脊損に打けるVUR の治療は，下部尿路通過障害の 改善に主眼が置かれるべさであり, 逆流防止術は, こ のような治療によっても消失せず，から症状の持続を みるような症例を対象とすべきであろら。

b）上部尿路拡張・膀胼変形

下部尿路通過障害にともならレ線上の尿路の変形の 中で膀胱壁の肉柱形成, 喤室様突出など膀胱の変形は, 上部尿路の变化に先行して比較的早期に出現する傾向 があり, 他覚的に排尿障害の存在を捉光, 治療のタイ 
ミングを知るらえで有効な指標となりらると思われ る. 今回の検討でも程度の差はあれ, 半数以上の症例 に膀脱変形が認められたが, その多くは radical TUR-P 施行後改善をみており, 下部尿路通過障害の 除去に加光, 2 報にて述べるごとく, compliance の増 加や, detrusor hyperreflexia の軽減消失も, この変化 に好影響を与えたと考えられる。

また術後にみられた水腎水尿管の改善に関し，尿管 膀脱移行部に括ける尿管機能に尿管鞘 (ureteral sheath）がその神経機構を介して関与していることが 指摘されて扣り 14)1617)， $\alpha$-adrenergicsを介した ureteral sheath の activityの六進が, 本法の sympathectomy 様効果により鎮静化したとする機能 的な要因の存在も考光られる.

以上のように radical TUR-Pは, 脊損神経因性膀胱 の治療法として多くの例で良好かつ安定したもので あった。本術式の及ぼす詳細な機序には不明な点が少 なくないが，単なる器質的通過障害の除去にとどまら ず, 膀脂頝部, 前立腺部尿道を介し利尿筋や外尿道括 約筋にわたる障害された神経機構にも本法がなんらか の影響を及ぼしている可能性が推察され興味深い, 比 較的長期の経過観察にて, ほぼ満足のいく成績を得ら れたことから，今後さらに症例を増やし検討を加えて いく予定である.

\section{結 語}

1）慢性期脊損100例に対し radical TUR-P を施行 した.このうち 90 例は本法施行後自排尿可能となり, 残尿率は術前 $46.9 \pm 34.4 \%$ から術後 $8.1 \pm 9.9 \%$, 尿流 量率は術前 $54 \pm 72 \mathrm{ml} / \mathrm{min}$, 術後 $207 \pm 166 \mathrm{ml} / \mathrm{min}$ とい ずれも有意の改善を認め, その後の長期経過観察でも 安定した排尿効率を保っている.

2）術後，13例に排尿障害の再発をみたが，原因に応 じた治療法を選択することにより，10例は自排尿に復 することができた。

3）高位䅡損の 5 例は, 本法によっても自排尿不能 で，これらはむしろ膀胀瘦が適応と考兄られた。

4）術前にVURを20例28尿管にみられたが，このら ち19尿管でその消失ないし軽減が認められた。VUR を伴わない上部尿路の拡張は11例にみられ, 術後 10 例 にその軽減ないし正常化をみた。膀胱変形は62例にみ られたが，らち50例は術後軽減した。

稿を終劣るにあたり，本研究に御協力いただいた美唄労 災病院若松不二夫名誉院長, 松野誠夫院長ならびに看護婦 諸姉に感謝いたします。
本論文の要旨は，第73回日本泌尿器科学会総会および第 19回日本パラプレジフ医学会において発表した。また本研 究は, 文部省科学研究費（B61480337）の援助による。

\section{文献}

1）岡村廉晴, 高松恒夫, 小柳知彦: 慢性期脊損者に招 けるプラン゙シンの使用経験. 日泌尿会誌, 74, 48-53, 1983.

2) Lapides, J., Diokno, A.C., Silber, S.J. and Lowe, B.S. : Clean intermittent selfcatheterization in the treatment of urinary tract disease. J. Urol., 107, 458-461, 1972.

3) Koyanagi, T., Arikado, K. and Tsuji, I. : Radical transurethral resection of the prostate for neurogenic dysfunction of the bladder in male paraplegics. J. Urol., 125, 521-527, 1981.

4）小柳知彦, 辻 一郎: 春損患者の尿路管理の実際 とその成績について. 西日泌尿会誌, 41, 511-522， 1979.

5) Koyanagi, T., Arikado, K., Takamatsu, T. and Tsuji, I.: Prostatic reflux : A simple radiographic sign in recognizing dysfunctioned voiding from external sphincter disorders. J. Urol., 128, 93-97, 1982.

6) Koyanagi, T., Arikado, T., Takamatsu, T. and Tsuji, I.: Relevance of sympathetic dyssynergia in the region of external urethral sphincter: Possible mechanism of voiding dysfunction in the absence of (somatic) sphincter dyssynergia. J. Urol., 127, 277-282, 1982.

7) Dwoskin, J.Y. and Perlmutter, A.D. : Vesicoureteral reflux in children: A computerized review. J. Urol., 109, 888-890, 1973.

8) Ruutu, M.L. and Lehtonen, T.A.: Bladder outlet surgery in men with spinal cord injury. Scand. J. Urol. Nephrol., 19, 241-246, 1985.

9）小柳知彦, 徳中荘平, 过一郎: 男子神経因性膀胱 の排尿障害治療における解剖学的な経尿道的前立 腺切除術の経験. 臨泌, 33, 173-178, 1979.

10) McNeil, J.E.: The prostate and prostatic urethra: A morphologic synthesis. J. Urol., 107, 1008-1016, 1972.

11) Greene, L.F. and Robinson, H.P.: Postoperative contracture of the vesical neck. IV. Prophylaxis and treatment. J. Urol., 95, 520-525, 1966.

12) Koyanagi, T. and Tsuji, I. : The mechanism of urinary continence after prostatectomy. Urol. Int., 32, 353-367, 1977.

13) Koyanagi, T. and Tsuji, I.: Study of ureteral reflux in neurogenic dysfunction of the bladder: The concept of a neurogenic ureter and the role 
of the periureteral sheath in the genesis of reflux and supersensitive response to autonomic drugs. J. Urol., 126, 210-217, 1981.

14）小柳知彦, 石川登喜治: 膀胼尿管逆流々潜在性無 抑制的神経因性膀胱. 西日泌尿会誌, 35, 473-480, 1973.

15）高松恒夫：脊損者における VUR と腎萎縮の関連 性について。目泌尿会誌，76，687-694，1985.

16) Block, C., Van Venrooij, Ger, E.P.M. and Cool- saet, Bo, L.R.A.: Dynamics of the ureterovesical junction: A qualitative analysis of the ureterovesical pressure profile in the pig. J. Urol., 134, 818-824, 1985.

17) Tempkin, A., Sullivan, G., Paldi, J. ánd Perkash, I.: Radioisotope renography in spinal cord injury. J. Urol., 133, 228-230, 1985.

（1987年 2 月 24 日受理） 